\title{
GENERALIZED INTEGRAL INEQUALITIES FOR CONVEX FUNCTIONS
}

\section{EMIN ÖZDEMIR AND ALPER EKINCI}

Abstract. In this paper, we prove some general inequalities for convex functions and give Ostrowski, Hadamard and Simpson type results for a special case of these inequalities.

Mathematics subject classification (2010): 26D15, 26D10.

Keywords and phrases: Convex functions, Hermite-Hadamard inequality, Simpson's inequality, powermean inequality, Ostrowski’s inequality; Hölder's inequality.

\section{REFERENCES}

[1] B. G. PACHPATTE, On some inequalities for convex functions, RGMIA Research Report Collection 6 , E (1) (2003)

[2] G. H. TOADER, On a generalization of the convexity, Mathematica 30, 53 (1988), 83-87.

[3] H. Kavurmaci, M. Avci AND M. E. Özdemir, New inequalities of Hermite-Hadamard type for convex functions with applications, Journal of Inequalities and Applications 86, 1 (2011).

[4] J. PEČARIĆ, S. VAROŠANEC, Harmonic polynomials and generalization of Ostrowski inequality with Applications in Numerical Integration, Nonlinear Analysis Series A: Theory, Methods and Applications 47, 1 (2011), 2365-2374.

[5] M. Z. Sarikaya, E. Set And M. E. Özdemir, On new inequalities of Simpson type for convex functions, RGMIA Research Report Collection 13, 2 (2) (2010).

[6] S. KovaČ, J. PEČARIĆ, Weighted version of general integral formula of Euler type, Math. Inequal. Appl. 13, 3 (2010), 579-599.

[7] S. S. Dragomir, R. P. Agarwal, Two inequalities for differentiable mappings and applications, Applied Mathematics Letters 11, 5 (1998), 91-95.

[8] U. S. KIRMACI, Inequalities for dfferentiable mappings and applications to special means of real numbers and to midpoint formula, Appl. Math. Comp. 147, 1 (2004), 137-146. 